\title{
The Hierarchical Procedures of Writing A Well Articulated Quantitative Academic Paper
}

\author{
Abdulrahman, $\mathrm{S}^{1} \& \mathrm{Musa}^{2}$ \\ ${ }^{1}$ Department of Accounting,Faculty of Social and Management Sciences,Bauchi State University, Gadau, \\ Bauch State, Nigeria. \\ ${ }^{2}$ Science Laboratory Technology Department, The Federal Polytechnic Bauchi, P.M.B. 0231, Bauchi- \\ Nigeria \\ Correspondence: Abdulrahman, S, Department of Accounting,Faculty of Social and Management \\ Sciences,Bauchi State University, Gadau, Bauch State, Nigeria.,Email: bdulningi17@yahoo.com, Tel: \\ $+2347035597220$
}

Received: January 19, 2018

Accepted: January 25, 2018

Online Published: January 29, 2018

\section{Abstract}

The study examined the logical stages of writing a well-articulated quantitative academic paper based on reviewing a well scholarly write ups. The paper is a conceptualised article that restricted itself within the saying and perceptions of the worldwide recognised scholars from the field of research methodology. As a researcher in the field of research, his abstract is expected to constitute of 7 points namely: Objectives, methodology, major findings, policy implication, and contribution to knowledge, major critics, and frontier of research.

Keywords: Academic Article, Quantitative Data, Data Collection, Theories.

\section{Introduction}

Structure is very crucial in constructing either academic paper or non-academic paper.The first thing before embarking on any research, you should have the following structure on ground because is very crucial in writing article/paper:-

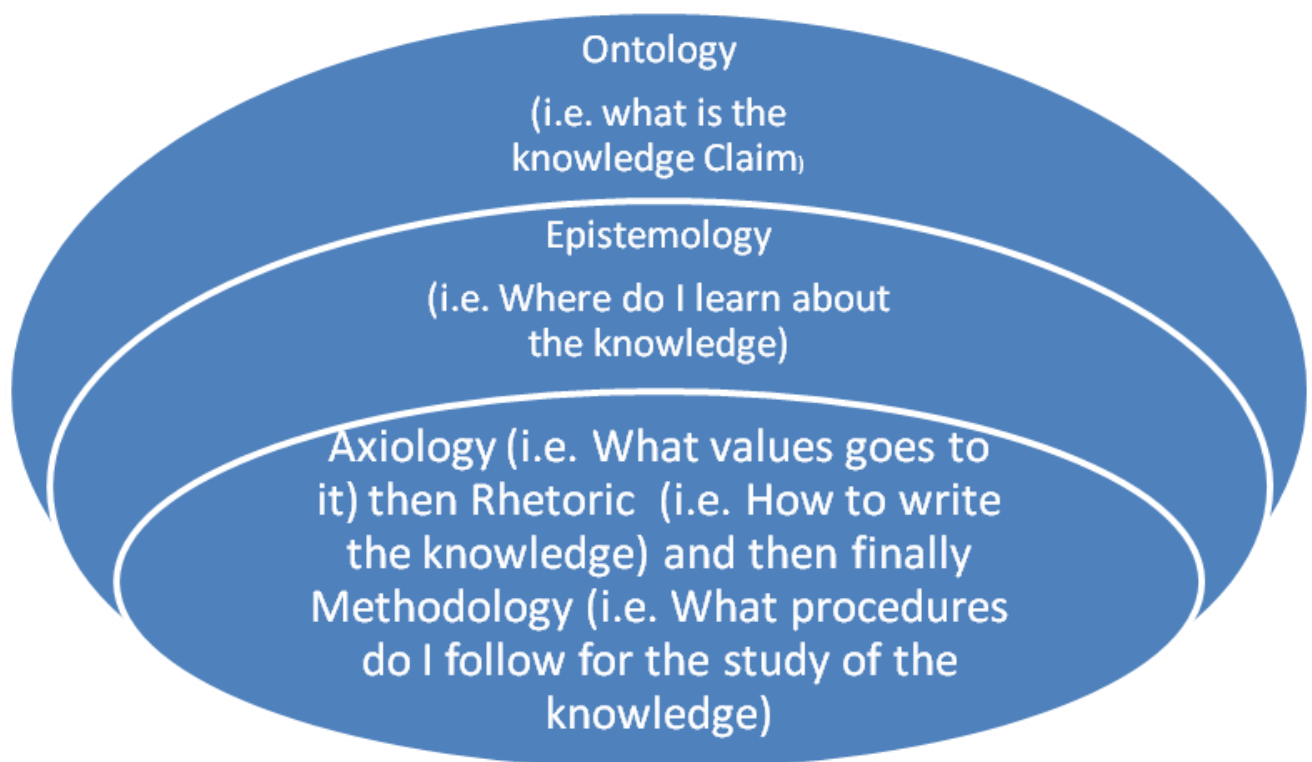

Source: Researchers Ideology 
In this stage the researcher is expected to warmup the topic by laying a foundation to the research topic. $\mathrm{He} / \mathrm{she}$ should look around all matters arising in respect to the topic such as the variables of the studies. It also proofs ones mastery of the area of research because a good background can only be achieved if the topic is well framed (i.e. A well framed topic satisfied the criteria of SMART where S-Specific not ambiguous, M-Measurable: all variables that cannot be proxies are not measurable, A-Attainable: topic should be realistically rational and achievable, R-Relevance: It should be relevant to the program today and even to the future and T-Time Bound: this refers to the time allotted to the work). The introductory part should also inter-relate the variables concurrently with the phenomenon by discussing the variables and showing how they relate to the topic. E.g. How Corporate Social Responsibility affects the Profitability of Deposits Money Banks (DBNs) in Nigeria.Then, the researcher is expected to articulate the following:

1.1 Statement of the problem:-This gives an insight into what prompts the researcher to carry out the research. Without articulated statement of problem in argumentative form or questionable form there is no research. It tells you a state of difficulty that researcher wants to resolve which is usually sourced from researcher experience, Gap from literature, consultation with experts, environmental affairs and even from theories. Any question that has an obvious answer or that has previously been answered is not a problem or a statement of fact about which the researcher has an established view or position is not a problem. Also, a statement that precludes enquiry is not a problem.

1.2 Research Questions:-Research questions are interrogative statements derived/flows from the statement of the problem. Usually it add colour to the work, it also put a researcher on track, so as at the end of the research the researcher will be able to define whether he has answered the questions raised. Lastly, it provides opportunities for readers to assess whether objectives are achieved or otherwise because at times some researchers are qualitatively and quantitatively bias in nature. E.g. Does Corporate Social Responsibility (CSR) has any influence on Profitability of Deposits Money Banks (DMBs) in Nigeria?

1.3 Objectives of the Study:- Ideally, objectives flow directly from the research questions. This contain what the researcher intends to achieve at the end of the day. Objectives should be stated by using specific terms and they should always carry the variables where they are obvious. Where one or more of the variables are hidden, the objectives should be stated in such a manner that it should be achieved at the end. Objectives can be stated in two different forms (i.e. General objectives and Specific objectives or Main objectives and other objectives).

1.4 Research Hypothesis:-is a tentative or conjectural statement/proposition of "if then" or "if not what". In other words a hypothesis is a tentative assumption made in order to draw out and test its logical and empirical consequences. It usually serves as guidelines to researchers. Some researchers are of the opinion that hypotheses should be stated in a null form because the aim is to reject the null hypotheses and it should be clear in simple term.

1.5 Significance of the Study:- Under this the researcher should state the beneficiaries of the study and how can the benefits accrue. E.g. Management, stakeholders, shareholders, researchers, analyst, creditors, competitors and then to the general public. How each of the beneficiaries will benefit.

1.6 Scope of the Study:- The researcher should discuss the period of the study and the specific variables to be included in the study.

2. Literature Review and Theoretical Framework:- A typical literature review should contain five (5) things namely:

2.1 Introduction: it should have an opening introduction that will itemise things that the section entails.

2.2Conceptualisation:-The researcher has to review the concepts and mention the difference and operationalised definitions of variables (i.e. how other literature defined them). Only those variables that are relevant to your studies and you are expected at the end of each definitions of your variable to give out your definition. E.g. Historical background about the concepts.

2.3 Review of Related Empirical Studies:- The researcher has to link his independent variable with the dependent variable or his dependent variable with the independent variable through reviewing other relevant and related studies. He has to have different sub-headings for reviewing individual independent variable. E.g. Corporate Social Responsibility (CSR) and Management/Financial Performance of Deposits Money Banks in Nigeria. Then this one will give you hints to link:

- Corporate Social Responsibility (CSR) and Profitabilityof Deposits Money Banksin Nigeria.

- Corporate Social Responsibility (CSR) and Efficiency of Deposits Money Banks in Nigeria.

- Corporate Social Responsibility (CSR) and Growth of Deposits Money Banks in Nigeria.

- Corporate Social Responsibility (CSR) and Liquidity of Deposits Money Banks in Nigeria.

- Corporate Social Responsibility (CSR) and Asset Quality of Deposits Money Banks in Nigeria. 
- Corporate Social Responsibility (CSR) and Capital Adequacy of Deposits Money Banks in Nigeria.

Theoretical Framework: The researcher has two options in presenting his theoretical framework, he can either explain the different theories that can back up his study and then finally state the theory underpinning his study or by going straight forward to the theory that underpinned his study. E.g. for Corporate Social Responsibility (CSR) and Financial Performance of Quoted Conglomerate in Nigeria. The theories that can come under this are:

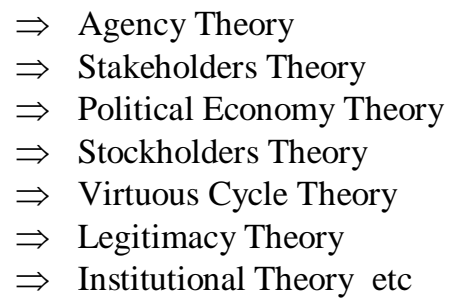

Then the researcher may decide to consider Stakeholders theory after stating solidified reasons of condemning other theories based on their deficiencies and giving concrete reasons for taking stakeholders theory to underpinned his study. Or assuming the researcher decided to use a topic that deals with consolidation of Banks in Nigeria. He may decide to use either:

- Financial Intermediation Theory or

- Concentration Theory or even

- Capitalisation Theory

Summary:- This sub-section entails the entire summary of section/chapter two (2) in a precisely and concisely manner.

2. Methodology of the Study:- A typical methodology should contain seven (7) things namely:

2.1 Introduction: it should have an opening introduction that will itemise things that the section entails.

2.2 Research Design: There is need for the researcher to have research design because it will help him to provide answers to research questions and to control variance. In other words is to test the validity of the proposed hypothesis. Since the research design is a blue print of procedures as such it can either be sampling research design, survey research design, experimental research design or causal effect research design.

2.3 Population and Sampling Design:- Since the population may be finite or infinite as such there is need for specification of what to use in either of the situation. For e.g. Banks in Nigeria is a finite population. Nevertheless, the researcher may decide to adopt a criteria so as to reduce the size of the population with the help of filtration(i.e. sample size) such as :

- First generation Banks

- Year of Incorporation

- Regional Banks are Exempted

- Banks that didn't published there financial statements online are exempted

- Quoted Banks in the Nigeria Stock Exchange (NSE)

While for infinite population the researcher has no any alternative rather than to use filter to reduce the size to consider unlike finite population he may decides to take the entire population to constitute his sample size (i.e. Census Approach). In the case of sample size it deals with part of the population deliberately taken to represent the population of the study. The researcher has to apply a proper sampling technique either probability sampling technique or Non-probability sampling technique and even under the probability sampling technique is it random sampling, systematic sampling, stratified sampling or area/cluster sampling and if it is under Non-probability sampling technique is it accidental sampling, Quota sampling, Judgemental sampling or Panel sampling technique.

2.4 Sources of Data Collection and Method of Data Collection:- the researcher needs to specify the sources of data collection is it primary source of data (i.e. Observation, group interview or individual Interview, Structured Questionnaire or Unstructured Questionnaire or even semi-structured Questionnaire ) or secondary source of data (i.e. Published materials such as journals, magazines, newspapers, books, students Viva or Dissertations, or even Graphs) or even both. He needs to categorically state it whether he will use quantitative data (i.e. Numerical Data) or qualitative data (i.e. Non-numerical Data) or even both in some scenarios. 
2,5 Techniques of Data Analysis or Variables Specification:- First of all the researcher needs to state the dependent and independent variables then specify the technique that will be adopted in analysing the data. E.g. is it statistical package for social science (SPSS Version 15.0, 16.0, 18.0 or 20.0), E-view, Stata Version 10.0 or Analyse it.

2.6 Model Specification:- The researcher has to state the model to use is it;

- He is adopting other researcher(s) model or

- He adopted other researcher(s) model or

- He developed a new model

Examples of models:

Cross sectional Model: - $Y_{i}=\alpha_{0}+\beta_{1} X_{1 i}+\beta_{2} X_{2 i}+\beta_{3} X_{3 i} \ldots+\beta_{n} X_{n i}+e_{n i}$

Time Series Model: $-Y_{t}=\alpha_{0}+\beta_{1} X_{1 t}+\beta_{2} X_{2 t}+\beta_{3} X_{3 t} \ldots+\beta_{n} X_{n t}+e_{n t}$

Panel/Longitudinal Model: $-Y_{\mathrm{it}}=\alpha_{0}+\beta_{1} X_{1 \mathrm{it}}+\beta_{2} X_{2 \mathrm{it}}+\beta_{3} X_{3 \mathrm{it}} \ldots+\beta_{\mathrm{n}} X_{\mathrm{nit}}+\mathrm{e}_{\mathrm{nit}}$

When you are dealing with one company but many years of their data is called time series data. If it is many companies but one year is called cross sectional data, but if you are dealing with many companies and many years is called longitudinal or panel data. All of the above aforementioned models are multiple or multivariate regression models because in each of them there is only one dependent variable (i.e. $Y_{i t}, Y_{t}$ and $\mathrm{Y}_{\mathrm{i}}$ ) and more than one independent variables. Bivariate or Simple regression model contain one dependent variable and one independent variable. The research is expected to gives a solidified justification of choosing either of the model.

2.7 Chapter Summary:- This sub-section entails the entire summary of section/chapter three (3) in a precisely and concisely manner.

3. Result and Discussion (i.e. Article or Paper) or Data Presentation and Analysis (i.e. Thesis or Dissertation) :- This chapter/section has the following things

3.1 Introduction:- it should have an opening introduction that will itemise things that the section entails.

3.2 Descriptive Statistics of the Data:- The researcher needs to present the summary of his descriptive statistics which consists of the Mean, Median, Mode, Minimum, Maximum, Variance, standard deviation, skewness and kurtosis. Usually presented in a tabular form. The descriptive statistics result show the normality of the data or otherwise. It is part of the reasons why some times researchers use to transform the data for it to be normalised. They take natural $\log$ of it to reduce the noise of the data. When a researcher found that the data is not normally distributed after transforming the data probably is because of either of the following reasons:

- Wrong selection of variables

- Wrong selection of measurement e.g. Ratios and Ordinal or Nominal and Scale or Scale and Ratios etc.

- Misrepresentation of variables .For example

Descriptive Statistics Table 1

\begin{tabular}{llllll}
\hline Variable & Mean & Median & Mode & $\begin{array}{l}\text { Standard } \\
\text { Deviation }\end{array}$ & Skewness Kurtosis \\
\hline $\begin{array}{l}\text { Corporate Social } \\
\text { Responsibility }\end{array}$ & & & & \\
\hline Working Conditions & & & & \\
\hline Environment & & & & \\
\hline Business Behaviour & & & & \\
\hline $\begin{array}{l}\text { Society and Local } \\
\text { Community }\end{array}$ & & & \\
\hline Firm Governance & & & & \\
\hline
\end{tabular}

Source: Drafted Sample of Descriptive Statistics Table

3.3 Hypotheses testing/ Main Result:-The researcher needs not to present the entire result in this section/chapter but the summary of the result to be presented here preferably in a tabular form. While the entire result will appear in appendix. The higher the number of other findings in line with your finding the insignificant the contribution you made. Example of a tabular result summary which need to be presented in the main report of findings: 
Table 2: Model Summary with Collinearity Test

\begin{tabular}{lllll}
\hline & Results & \multicolumn{3}{c}{ Collinearity Test } \\
\hline $\mathrm{R}$ & .87 & VARIABLES & $\begin{array}{l}\text { Tolerance } \\
(\mathrm{TV}):\end{array}$ & $\begin{array}{l}\text { Value } \\
\text { Variance Inflation Factor } \\
\text { (VIF): }\end{array}$ \\
\hline $\mathrm{R}^{2}$ & 0.73 & ER & 0.992 & 1.008 \\
\hline Adj R & 0.65 & CP & 0.899 & 1.112 \\
\hline F Change & 16.385 & EMS & 0.893 & 1.120 \\
\hline $\begin{array}{l}\text { Std. Error } \\
\text { Estimate }\end{array}$ & 0.55331 & & & \\
Mean of Y & 0.9674 & & & \\
\hline F-Statistics & 0.006 & & & \\
\hline
\end{tabular}

Source: Drafted Sample of Descriptive Statistics Table

From the table above the correlation coefficient represented by R appeared to be approximately 0.87 which can be considered as a strong correlation. As for the extent to which the independent variables explains the dependent variables called coefficient of determination which is represented by $\mathrm{R}^{2}$ is $73 \%$ and when strictly look at in more refined form it explains up to $73 \%$. The overall fitness of the model represented by Fstatistic has a value of 16.385 which appeared significant at $1 \%$. This is backed up by the standard error of estimate value of 0.55331 which appeared less than the mean of Y. Likewise the tolerance value (TV) and variance inflation factor (VIF) measures the degree to which each independent variable explained the other independent variable. The result of TV and VIF shows that there is lack of multicollinearity among the independent variables which is ideally in order. P-values usually show the individual fitness of each of the variable while F-statistics show the overall fitness of the model but it is not indicating the auto correlation or series correlation that one is Durbin-Watson work. Some people called it DW which stands for DurbinWatson, it usually show us whether there is auto correlation which according to some authors is within the range of 1.5 to 2.5 anything below 1.5 and above 2.5 signifies series correlation.

4. Summary, Conclusion and Recommendation (i.e. Thesis or Dissertation) or Conclusion (i.e. Paper/Article):- There is no introduction and no summary at the end of this section/chapter. Nevertheless, this section/chapter contains the following:

4.1 Summary: - this implies the entire summary of the work from the first section/chapter to the last chapter/section. This summary is broader than the ordinary summary of the individual chapter's/ Section's.

4.2 Conclusion: - It is based on the findings from the study that a researcher makes his conclusion concerning the study.The conclusion depends on the number of hypotheses and the findings. The researcher has to harmonise his conclusions with his findings.

4.3 Recommendation: this usually flows only from the findings of the study. Restrict your recommendations to only your findings assuming you have three (3) objectives you are expected to have nothing less than three (3) findings and three (3) recommendations respectively. Therefore, recommendations go along with findings. It can be numbered according to the findings.

4.4 Area for further Research: - Researcher can suggest areas for further study/research but it is optional. Is just that it add the beauty and colour of the work.

4.5 References: this serve as a guide to source materials in which more detailed statistics can be found and which should be checked to assure getting accurate and authoritative information. While bibliography is the list of books on a specific subject by a particular author which is used by an author whether such works were referred to in the paper or not. As such bibliography is more preferable than referencing and it can be in form of American Psychological Association (APA) style or Harvard style.

\section{References}

Abdulrahman, S. (2013), the influence of corporate social responsibility on profit after tax of some selected deposit money banks in Nigeria. Educ. Res. 4(10):722-732

Adebayo, O., Oluwatoyosi, O.T. \& Elizabeth, O.M. (2012),"Corporate Social Responsibility Reporting and Financial Performance of Money Deposit banks in Nigeria Prime Journal of Business Administration and Management (BAM) ISSN: 2251-1261. Vol. 2(11), Pp. 758- 769, November 13th, 2012. $\quad$ www.primejournal.org/ BAM @ Prime Journals 
Agbadudu, A.B. (2002): "Major Statistics Tools and their Uses in Research Analysis" Research Design and implementation in Accounting and Finance. University of Benin Press, Benin Pp. 101114

Andy, F. (2000): Discovering Statistics: using SPSS for Windows, London: Sage Publication.

Aupperle, K. E. (1991), the use of forced choice survey procedures in assessing corporate Social orientation. In Research in corporate social performance and policy, Ed. J.

E. Post Greenwich: C. T. JAI Press

Cohen,J. (1988), Statistical power analysis for the behavioral sciences, $2^{\text {nd }}$ Ed. Hillsdale, $\quad$ New jersey: Erlbaum.

Dwivedi, D.N. (2003): Managerial Economics; Vikas publishing PVT Ltd New Delhi, 6thEdition Environics (environics international Ltd). (2002)."corporate social responsibility monitor Toronto: Author

Ernst, A. \& G. Young (2002) Global Survey. http://www.golbalissues.org/print/article/723

Ernst. \& Ernst (1978), 1977 survey of fortune 500 Annual Reports. Clever land Ohio

European Commission (2001), Green Paper "Promoting a European Framework for Corporate Social Responsibility, Brussels, Pp. 32

Freeman, R. E. (1984), "Strategic Management: A Stakeholder Perspective, Englewood Cliffs: Prentice Hall. U.S.A

Friedman, M. (1962), Capitalism and freedom, Chicago: University of Chicago Press

Glautier, M.W.E and Underdown, B. (2001): Accounting theory and practice; Agency Ltd. Tottenham court Road London W1T 4LP $7^{\text {th }}$ Edition

Gray, R., Owen, D., \& Adams, C. A. (1996), Accounting and Accountability: Changes and Challenges in Corporate Social and Environmental Reporting, Prentice-Hall, London

Green, W.H. (1997), Econometric Analysis, Upper saddle River, NJ: Prentice Hall

Guobadia, A. (2000): Protecting minority and public interests in Nigeria company law: The corporate affairs commission as a corporation’s ombudsman. In McMillan, $\quad$ F. (Ed.), International Company Law Annual, 1, 81-145

Kurtz, B. (2006) Contemporary Marketing. 9th edition United Kingdom

Robotham, D. (2005). Political Economy.A Handbook of Economic Anthropology. J. G. Northampton, MA, Edward Elgar ISBN 1-84376-175-0 pp. 41-58

Sabari, M.H. (2013), "Risks and Uncertainties as Determinants of Size of Recapitalized in Nigeria" International Journals of Marketing and Technology, Volume 2 2248-1058

Tilling: M. V. (2004), Refinements to legitimacy theory in social and environmental Flinders University, South Australia commerce research paper ISSN: $1441-3906$

Ullman A. A. (1985), "Data in Search of a Theory: A Critical Examination of the Relationships among Social Performance, Social Disclosure, and Economic Performance of U.S Firms". Acad. Manage. Rev. 10: pp. 540-557

Werhane, Patricia H. \& R. Edward Freeman (1999), "Business Ethics: The State of the Art", International Journal of Management Reviews. 1 (1), pp. 1-16

\section{Copyrights}

Copyright for this article is retained by the author(s), with first publication rights granted to the journal.

This is an open-access article distributed under the terms and conditions of the Creative Commons Attribution license (http://creativecommons.org/licenses/by/4.0/). 